\title{
A comparison of shrinkage cracking between clay minerals by crack parameters using image analysis
}

\author{
Vo Dai Nhat
}

\begin{abstract}
Experiments have been conducted in laboratory to present a comparison of shrinkage cracking based on an observation and a quantitative determination of crack parameters. Photographs of surface cracks for three different types of clay mineral belonging to different groups - Bentonite, Kaolinite and Illite - are processed using image analysis. Each of soil types is tested with four sample thicknesses ranging from 5 to $20 \mathrm{~mm}$ at an interval of $5 \mathrm{~mm}$. The measurements of crack parameters for clay mineral soils show that area and width of cracks in case of Bentonite are much larger than those while length of cracks appears to be slightly less than that in other cases. Number of cracks in case of Bentonite are smaller than those in cases of Kaolinite and Illite. Additionally, compared with Illite, area, length and width of cracks in case of Kaolinite are slightly larger while the other crack parameters seem to be same.
\end{abstract}

Index Terms-Shrinkage cracking, Bentonite, Kaolinite, Illite, image analysis, crack parameters.

\section{INTRODUCTION}

$\mathrm{A}$ $\mathrm{s}$ water evaporates from the soil surface, the tensile stress develops in the soil system. The soil tends to crack when the tensile stress exceeds the tensile strength. A large number of papers investigated on soil cracking have been recently published since cracking in soils has been the subject of investigation for many years. Image analysis has been widely used to analyze and determine the quantitative as well as qualitative measurements of soil cracking.

A theoretical study on soil cracking was developed by Morris et al. [8] based on elasticity theory, the transition between tensile and shear

Manuscript Received on August 7th, 2017. Manuscript Revised December 25th, 2017

Vo Dai Nhat - Faculty of Geology and Petroleum Engineering, Ho Chi Minh City University of Technology VNU-HCM (e-mail: nhatvodai@ hcmut.edu.vn). failure, and linear elastic fracture mechanics. Subsequently, many authors have attempted to study on soil cracking in various aspects on several types of materials [1, 2, 4-7,9-11, 13-15]. Cracking in soils due to drying is controlled by partly soil suctions and partly soil properties including mainly the physical and the chemical properties. The results showed that cracking of clay generally depends on experiment conditions such as base material, soil density, the desiccation rate, and thickness of the sample. Conditions that govern the characteristics of soil cracking may be categorized as two separate terms: extrinsic and intrinsic conditions [4]. Extrinsic conditions include fundamentally temperature, relative humidity, and wind velocity whereas moisture condition, structure of material, degree of packing, physical and chemical composition, etc are belonged to intrinsic conditions.

Vallejo and Mawby [12] investigated the behavior of the shear strength of granular material-clay mixtures by measuring the porosity of the sample system. In addition, saturated permeability, soil-water characteristic curve and shrinkage characteristics were also affected by coarse-grained content [3]. Furthermore, soil cracking also influenced soil structure and behavior [4]; volumetric shrinkage strain, compaction water content and hydraulic conductivity [1].

Nowadays, clay minerals have become the important materials for construction purposes. Although there have been a number of papers on the criteria for soil cracking subjected to drying; however, the investigations of shrinkage cracking on clay minerals have not been studied yet. Therefore, in this paper, we study on the characteristics of shrinkage cracking in clay minerals by quantifying the measurements of several crack parameters. 


\section{MATERIALS}

For laboratory measurements, three types of clay mineral - Bentonite, Kaolinite and Illite which developed the cracks due to drying are used. The properties of the soils used in this study are summarized in Table 1. The experiments were performed in a rectangular steel tray. Firstly, the soil was mixed carefully with water and stirred in a stirrer for half an hour to constitute a paste. An initial water content of the mixture was about 1.5 times higher than liquid limit of each type of soils. Secondly, the mixture was poured in the tray and uniformly spread to make the surface flat. Finally, the system was balanced and allowed to dry naturally in laboratory at room conditions.

TABLE 1

PROPERTIES OF THE SOIL SAMPLES USED IN THIS STUDY

\begin{tabular}{lccccccccccc}
\hline \hline Soil types & $\begin{array}{c}\mathrm{LL} \\
{[\%]}\end{array}$ & $\begin{array}{c}\mathrm{PL} \\
{[\%]}\end{array}$ & $\begin{array}{c}\text { PI } \\
{[\%]}\end{array}$ & $G_{S}$ & $\begin{array}{c}D_{10} \\
{[\mathrm{~mm}]}\end{array}$ & $\begin{array}{c}D_{30} \\
{[\mathrm{~mm}]}\end{array}$ & $\begin{array}{c}D_{60} \\
{[\mathrm{~mm}]}\end{array}$ & $C_{u}$ & $C_{c}$ & Classification & Name \\
\hline Bentonite & 131.73 & 45.25 & 86.48 & - & - & - & - & - & - & $\mathrm{CH}$ & Fat clay \\
Kaolinite & 42.07 & 25.40 & 16.67 & 2.646 & 0.0004 & 0.0039 & 0.0163 & 40.75 & 2.33 & $\mathrm{CL}$ & Lean clay \\
Illite & 27.18 & 17.48 & 9.70 & 2.779 & 0.0029 & 0.0079 & 0.0259 & 8.93 & 0.83 & $\mathrm{CL}$ & Lean clay \\
\hline \hline
\end{tabular}

Note: classification of studied soil is based on gradation curve and plasticity chart (Adapted from Casagrande, 1948; Howard, 1977). The unified system designates silt by the letter M, clay by C. Soils with liquid limits of less than 50 are classified as having low to medium plasticity (L), greater than 50 as having high plasticity $(H)$.

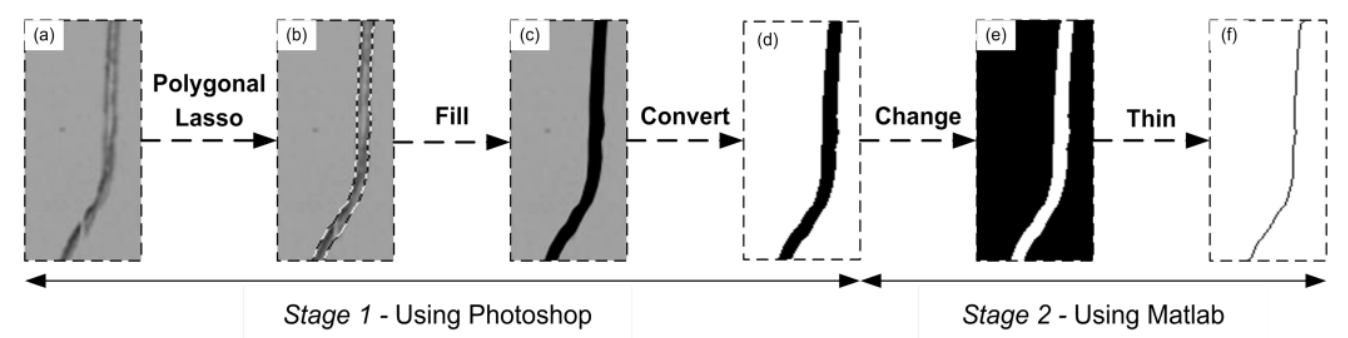

Figure 1. Steps of image analysis processing

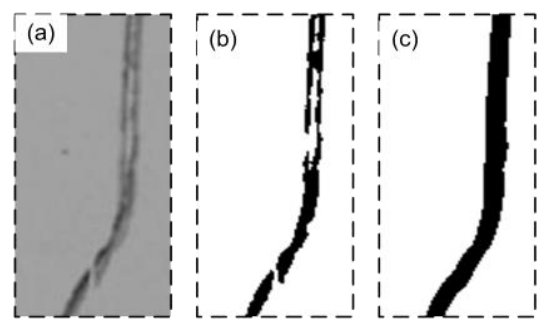

Figure 2. Two processes of converting (a) crack image to binary image: (b) automatic, and (c) manual 


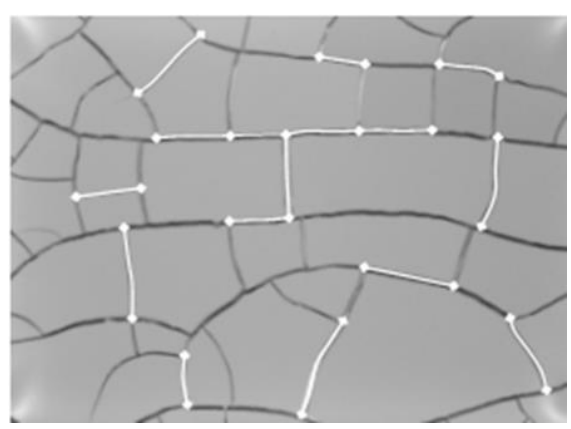

Figure 3. Illustration of the individual cracks limited by two-diamond ends
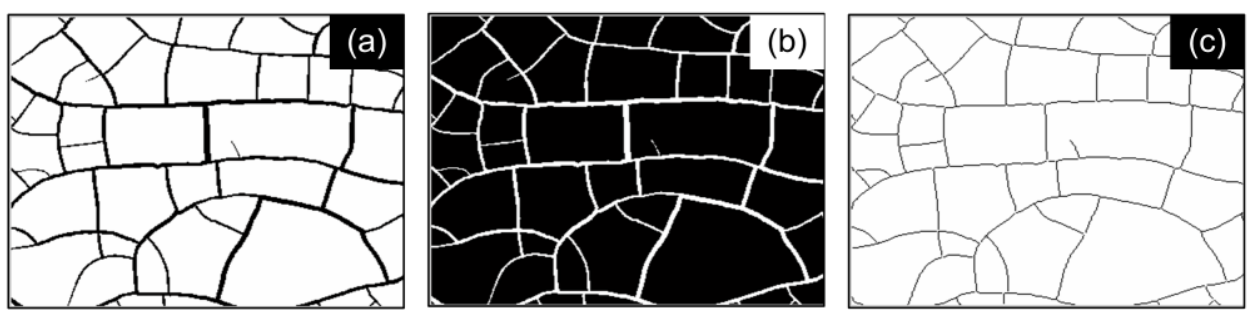

Figure 4. Process for calculating crack parameters: (a) binary, (b) changed and (c) thinned images

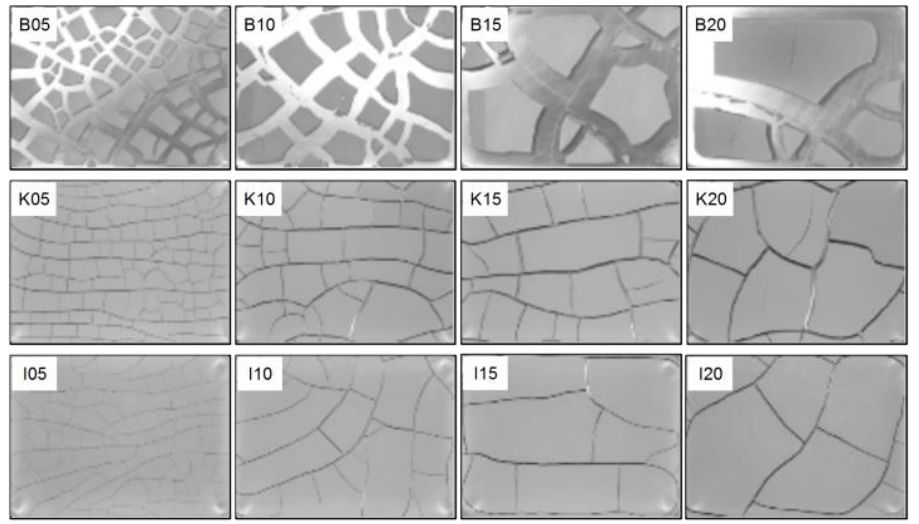

Figure 5. The cracking images of Bentonite (B), Kaolinite (K), Illite (I) with different thicknesses: 5, 10, 15 and $20 \mathrm{~mm}$. The images are as a dimension of 1280x960 pixels corresponding to the real size of $220 \mathrm{~mm}$ by $165 \mathrm{~mm}$

\section{METHODS}

\subsection{Imageanalysis}

Evaporation appears from the soil surface. Consequently, the mass of the soil system will be decreased by a loss of water as drying time increases. As water is lost from the surface soil mass, tensile forces are established in the drying surface layer and soil also loses its ability to relieve these tensile forces. These stresses are finally relieved by the occurrence of cracks that grow up at the surface of the soil. As the drying process develops continuously, cracks are formed

successively. An individual crack propagates until it contacts with the other cracks or the borders of the container. Consequently, a network of cracks is established.

Images of soil cracking captured by a digital camera were primarily processed by using an application of control point selection technique [9]. To quantify measurements of soil cracking through crack parameters, the images were required to be converted to binary. Figure 1 illustrates all steps of image processing applied to 
an individual crack Figure 1a as an example. The boundary of crack was outlined using Polygonal Lasso tool, which separated crack from the background surface as shown in Figure 1b. The separated crack part was, then, filled by black color Figure 1c. The image was converted automatically to binary one by selecting a fixed threshold value Figure 1d. The irrelative parts were erased using cutter tool. These four steps are referred to as the first stage in image analysis processing. The second stage was carried out automatically by applying a written program made in Matlab software. Crack was occupied by black pixels while white pixels were considered as the background. Area of crack was computed automatically by counting the total number of pixels. To measure crack length, color of crack was required to be changed from black to white Figure 1e for applying an algorithm 'thin' defaulted in the program. Using this algorithm, crack was thinned to line automatically Figure 1f. Length of crack was calculated by summing distances of continuously consecutive pixels.

Figure 2 illustrates the reason why we used image analysis processing manually in the first stage. Due to the similar color at several points between crack and the background, hence when the image Figure 2a was converted to binary automatically Figure $2 b$, a lot of information of crack will be lost inside crack as well as along its boundary. Furthermore, as seen in a step from Figure 1e to Figure 1f, to thin crack to line, it was required that color of crack must be continuously. Although the manual processing spends time, but not much; however, the result will be more accurate with a clearly separate crack Figure $2 \mathrm{c}$.

\subsection{Calculation of crack parameters}

A crack was defined by a set of pixels limited by two ends Figure 3; and a pattern was a set of separately continuous connected-neighbor pixels. Subsequently, several crack parameters are calculated as follows:

\subsubsection{Area of cracks}

An example of binary image converted from the image given in Figure 3 was shown in Figure 4a. Area of cracks is computed automatically by counting the total number of black pixels.

\subsubsection{Length of cracks}

As mentioned, to measure length of cracks, the color of cracks was changed from black to white Figure $4 \mathrm{~b}$. The command 'bwmorph' was used to calculate length of cracks with 'thin' option.
Length of cracks is calculated by summing distances of black pixels Figure 4c.

\subsubsection{Width of cracks}

As a result from determination of area and length of crack, width of cracks is defined simply as a ratio of area to length of cracks.

\subsubsection{Number of cracks}

Generally, after initiating, crack will develop toward both directions at its tips. When it touches either other cracks or the borders of the container, it stops increasing its length. As a result, new cracks are established in the system of cracks. Number of cracks are determined by counting the total cracks in the system of cracks, respectively.

\section{RESULTS AND DISCUSSION}

\subsection{Observation}

As thickness increases, width of cracks will increase. That can be explained by an increase of thickness leads to increasing the amount of shrinkage potential in the soil system. Furthermore, with smaller thickness, the differentiation of shrinkage potential in the layered-soil system appears at several points simultaneously. It leads to an appearance of many cracks formed in drying process. The appearance of cracks reduces shrinkage potential in the soil system; thus width of cracks in case of smaller thickness is smaller than that of cracks in case of larger thickness.

Secondly, a comparison of cracking between the soils is observed. Bentonite has been known as one of the expansive clays with high shrinkage potential; as a result, it presents the largest amount of cracking as shown in Figure 5. In detail, area and width of cracks formed by Bentonite are much larger than those by other clay mineral soils, i.e. Kaolinite and Illite.

Generally, Illite has higher liquid limit, plastic limit and plasticity index than Kaolinite. However, for the soils used in this study, Kaolinite gives liquid limit, plastic limit and plasticity index which are higher than Illite does. It can be explained that the soils used are not truly pure clay minerals, i.e. not truly pure Bentonite, Kaolinite and Illite. They are only a derivative of pure clay minerals with their individual compositions. Consequently, the quantity of Kaolinite results in larger amount than that of Illite as seen in Figure 5. 


\subsection{A quantitative measurements}

\subsubsection{Area of cracks}

Figure 6 presents the measurements of crack area for three clay mineral soils. Area of cracking in case of Bentonite is really much larger than others while Illite gives smallest value of crack area. It is about $20,000 \mathrm{~mm}^{2}$ for Bentonite while Kaolinite gives about $3,600 \mathrm{~mm}^{2}$ and that is about $1,600 \mathrm{~mm}^{2}$ for Illite. Compared with the real size of the container as a dimension of $220 \mathrm{~mm}$ by 165 $\mathrm{mm}$, they are about 55\%, 9.9\% and $4.4 \%$, respectively. As shown in Figure 6, values of area of cracks formed with four sample thicknesses are actually same for each of clay mineral soils. As explained in section 4.1, because Bentonite has much higher shrinkage potential than Kaolinite and Illite; therefore, it gives area of cracks much higher than that in cases of Kaolinite and Illite. Furthermore, as given in Table 1, Kaolinite with higher plasticity index than Illite causes higher value of crack area.

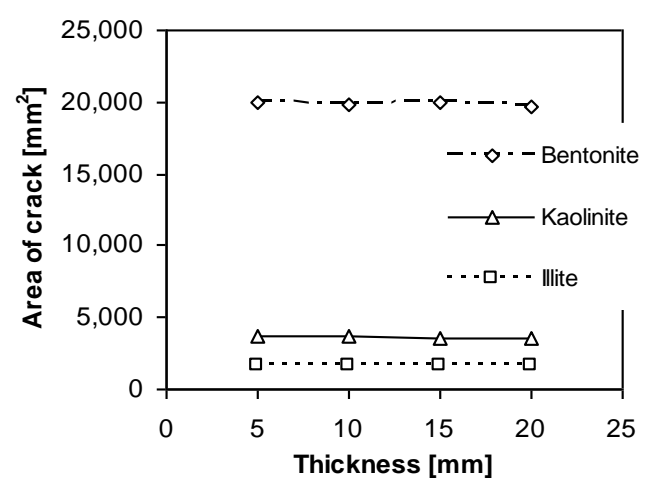

Figure 6. Measurements of crack area for clay mineral soils

\subsubsection{Length of cracks}

A comparison of length of cracks between clay mineral soils is shown in Figure 7. Length of cracks in case of Kaolinite is slightly higher than two other cases. Beside, compared with Illite, Bentonite gives slightly smaller value of length of cracks; except for thickness of $10 \mathrm{~mm}$. That is caused by taking into account of cracks appeared along the border of container by shrinkage. As a result of the effect of thickness on cracking, increasing thickness reduces length of cracks.

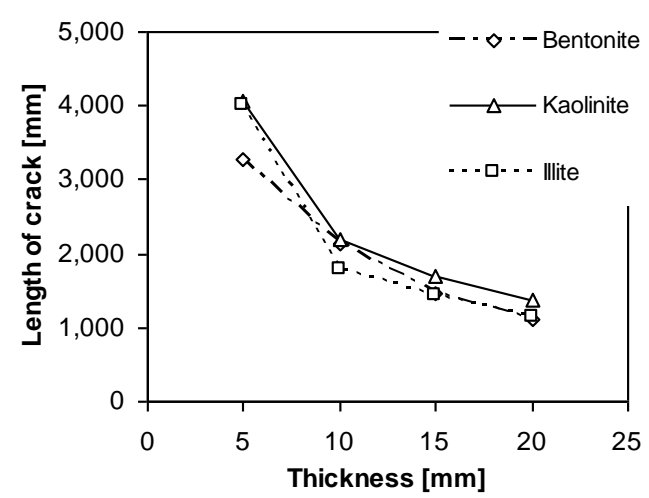

Figure 7. Measurements of crack length for clay mineral soils

\subsubsection{Width of cracks}

As observed in Figure 5, width of cracks formed by Bentonite is much larger than that formed by Kaolinite and Illite, their measurements are shown in Figures 8 and 9 for maximum and average values, respectively. The results in Figures 8 and 9 present similar variations. Maximum and average widths of cracks in case of Bentonite are much larger than those in cases of Kaolinite and Illite. Meanwhile, those of Kaolinite case give slightly larger values compared with Illite. As thickness increases, width of cracks will increase due to an increase of shrinkage potential. The slope of the variations in case of Bentonite is steeper than that of Kaolinite and Illite.

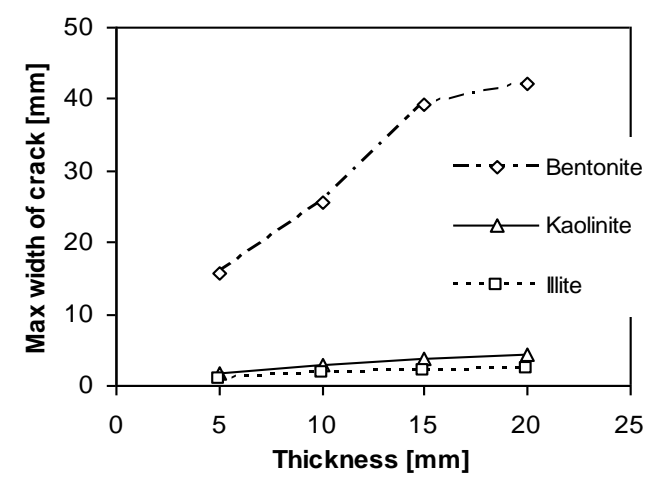

Figure 8. Measurements of maximum width of crack for clay mineral soils 


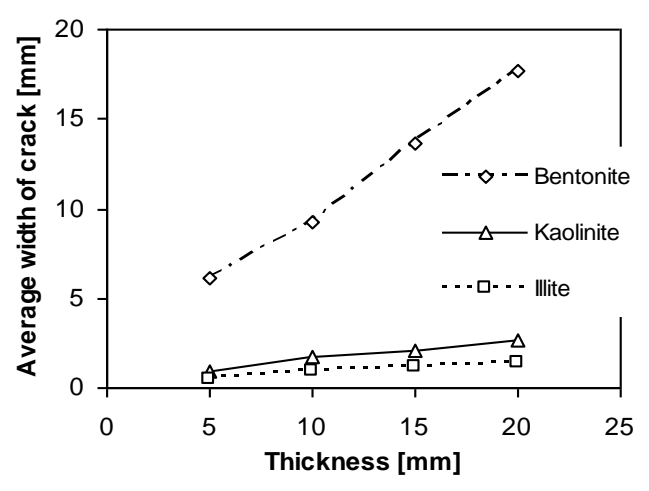

Figure 9. Measurements of average width of crack for clay mineral soils

For total evaluation of the measurements, the individual width of cracks are determined separately and the variations of crack width with number of crack are given in Figure 10. Figures 10(a), (b), (c), and (d) are for the sample thicknesses of 5, 10, 15 and $20 \mathrm{~mm}$, respectively. The results for Bentonite are plotted by dash lines, Kaolinite by continuous lines, and Illite by dot lines. The results in Figure 10 are as same as in Figures 8 and 9; i.e., Bentonite gives much larger crack widths than Kaolinite and Illite, and Illite has smallest width of cracks.

\subsubsection{Number of cracks}

Figure 11 presents the variation of number of cracks with sample thickness for clay mineral soils. In two cases of Kaolinite and Illite, the number of cracks appears to be same for the cases of thickness. Both of them are higher than that formed by cracking in case of Bentonite. Especially, with thickness of $5 \mathrm{~mm}$, the difference is much larger than the other cases of thicknesses. As thickness decreases from $5 \mathrm{~mm}$ to $10 \mathrm{~mm}$, number of cracks reduces dramatically. The decreasing rate reduces gradually as thickness increases from $10 \mathrm{~mm}$ to $20 \mathrm{~mm}$.

\section{CONCLUSIONS}

A comparison of shrinkage cracking between three types of clay mineals is examined by observing and measuring the quantity of several crack parameters. Three are derivatives of clay mineral groups consisting of Bentonite, Kaolinite and Illite. The experiments are conducted in laboratory at room conditions. The results show that the quantity of cracking density in case of Bentonite is much higher than the others. Compared with Kaolinite, cracking density in case of Illite is slightly smaller. As the thickness increases, the total length of cracks decreases and the maximum and average width of cracks increase while the total areas of cracks are same.
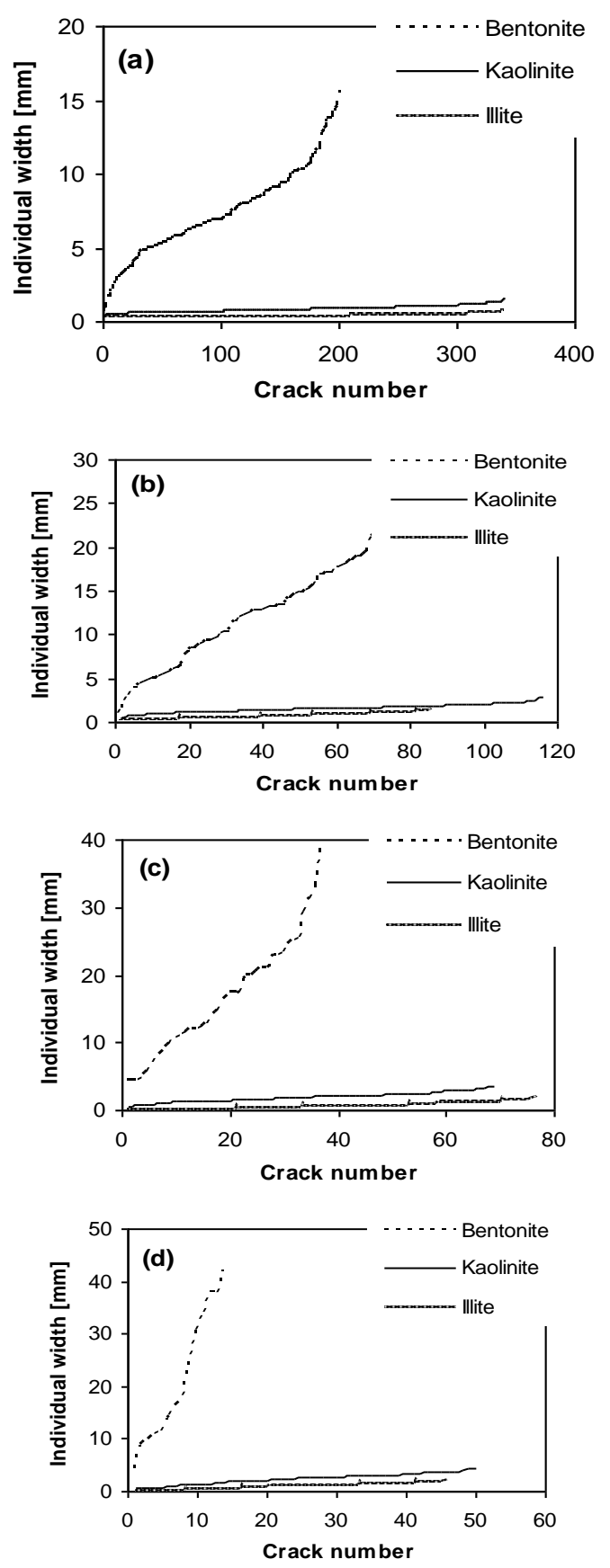

Figure 10. Distribution of width of the individual cracks for clay mineral soils with different thicknesses: (a) $5 \mathrm{~mm}$, (b) 10 $\mathrm{mm}$, (c) $15 \mathrm{~mm}$ and (d) $20 \mathrm{~mm}$ 


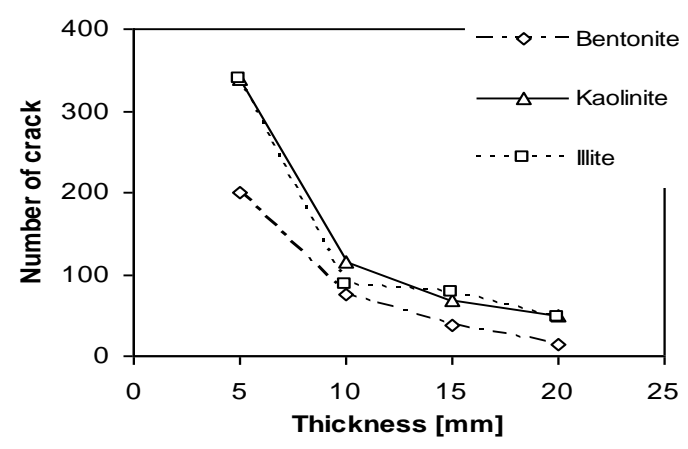

Figure 11. Variation of number of crack with thickness for clay mineral soils

\section{REFERENCES}

[1] B. A. Albrecht, and C. H. Benson, "Effect of desiccation on compacted natural clays." Journal of Geotechnical and Geoenvironmental Engineering, Vol. 127, No. 1, pp. 67-75, 2001.

[2] V. Y. Chertkov, and I. Ravina, "Morphology of horizontal cracks in swelling soils." Theoretical and Applied Fracture Mechanics, Vol. 31, Issue. 1, pp. 19-29, 1999.

[3] I. G. B. Indrawan, H. Rahardjo, and E. C. Leong, "Effects of coarse-grained materials on properties of residual soil.” Engineering Geology, Vol. 82, Issue. 3, pp. $154-164,2006$

[4] J. K. Kodikara, S. L. Barbour, and D. G. Fredlund, "Desiccation cracking of soil layers." Unsaturated Soils for Asia, Rahardjo, Toll \& Leong (eds). Balkema, Rotterdam, ISBN 905809139 2, pp. 693698, 2000.

[5] J.-M. Konrad, and R. Ayad, "Desiccation of a sensitive clay: Field experimental observations." Canadian Geotechnical Journal, Vol. 34, No. 6, pp. 929-942, 1997.

[6] N. Lecocq, and N. Vandewalle, "Dynamics of crack opening in a one-dimensional desiccation experiment." Physica A: Statistical Mechanics and Its Applications, Vol. 321, Issues. 3-4, pp. 431-441, 2003.

[7] D. Mal, S. Sinha, S. Mitra, and S. Tarafdar, "Formation of crack networks in drying laponite films." Physica A: Statistical Mechanics and Its
Applications, Vol. 346, Issues. 1-2, pp. 110-115, 2005.

[8] P. H. Morris, J. Graham, and D. J. Williams, "Cracking in drying soils." Canadian Geotechnical Journal, Vol. 29, No. 2, pp. 263-277, 1992.

[9] T. K. Min, and N. Vo-Dai, "A simple model of shrinkage cracking development for kaolinite." Journal of the Korean Geotechnical Society, Vol. 23, No. 9, pp. 29-37, 2007.

[10] X. Peng, R. Horn, S. Peth, and A. Smucker, "Quantification of soil shrinkage in 2D by digital image processing of soil surface." Soil \& Tillage Research, Vol. 91, Issues. 1-2, pp. 173-180, 2006.

[11] Y. Y. Tay, D. I. Stewart, and T. W. Cousens, "Shrinkage and desiccation cracking in bentonitesand landfill liners." Engineering Geology, Vol. 60, Issues. 1-4, pp. 263-274, 2001.

[12] L. E. Vallejo, and R. Mawby, "Porosity influence on the shear strength of granular material-clay mixtures." Engineering Geology, Vol. 58, Issue. 2, pp. 125-136, 2000.

[13] B. Velde, "Structure of surface cracks in soil and muds." Geoderma, Vol. 93, Issues. 1-2, pp. 101-124, 1999.

[14] B. Velde, "Surface cracking and aggregate formation observed in a Rendzina soil, La Touche (Vienne) France." Geoderma, Vol. 99, Issues. 3-4, pp. 261276, 2001.

[15] D. C. Wijeyesekera, and M. C. Papadopoulou, "Cracking in clays with an image analysis perspective." Clay Science for Engineering, Adachi \& Fukue (eds) Balkema, Rotterdam, ISBN 905809175 9, pp. 437-482, 2001.

Vo Dai Nhat received the Ph.D degree from University of Ulsan, Ulsan City, Korea in 2008.

He became a lecturer at Ho Chi Minh City University of Technology - VNU-HCM (HCMUT) in 2009.

His major is geotechnical engineering and his focused research areas are soft ground improvement, geotechnics, slope stability analysis, settlement, retaining wall, ... 


\title{
So sánh hiện tượng nứt do co ngót giữa các khoáng vật sét bằng các thông số vết nứt sử dụng phương pháp xử lý ảnh
}

\author{
Võ Đại Nhật
}

Tóm tắt-Các thí nghiệm được thực hiện trong phòng để so sánh kết quả của hiện tượng nứt do co ngót dựa trên kết quả quan sát và tính toán các thông số vết nứt. Các ảnh chụp vết nứt bề mặt của ba loại khoáng vật sét khác nhau - Bentonite, Kaolinite, và Illite - được xử lý bằng phương pháp xử lý ảnh. Mỗi loại đất được thí nghiệm với bốn trường hợp bề dày khác nhau, từ 5 đến $20 \mathrm{~mm}$ với gia số là 5 mm. Kết quả tính toán các thông số vết nứt cho thấy rằng diện tích và bề rộng vết nứt của đất sét Bentonite lớn hơn nhiều trong khi chiều dài các vết nứt nhỏ hơn so với hai loại đất còn lại. Số vết nứt trong trường hợp đất sét Bentonite nhỏ hơn trường hợp Kaolinite và Illite. Hơn nữa, so sánh với khoáng vật sét Illite, diện tích, chiều dài và bề rộng của vết nứt đối với trường hợp Kaolinite là lớn hơn trong khi các thông số vết nứt khác hầu như giống nhau.

Tù khóa-Nứt co ngót, Bentonite, Kaolinite, Illite, xử lý ảnh, thông số vết nứt. 